\title{
PEMILIHAN STRATEGI PEMASARAN DI KAMPOENG KOPI BANARAN MENGGUNAKAN PENDEKATAN METODE ANALYTICAL NETWORK PROCESS (ANP) DAN TECHNIQUE FOR ORDER PREFERENCE BY SIMILARITY TO AN IDEAL SOLUTION (TOPSIS)
}

\author{
Aries Susanty $^{*}$, Woro Adiati ${ }^{*}$ \\ Program Studi Teknik Industri Fakultas Teknik Universitas Diponegoro \\ Jl. Prof. Soedarto, SH Tembalang Semarang 50239
}

\begin{abstract}
Abstrak
Kampoeng Kopi Banaran belum dapat mencapai laba sesuai dengan target yang telah ditetapkan. Diduga hal ini terjadi karena semakin banyaknya pesaing dengan usaha sejenis, seperti Cimory, Kampoeng Rawa, Tlogo Plantation, Salib Putih, dan Umbul Sidomukti serta belum dimilikinya strategi pemasaran yang tepat oleh Kampoeng Kopi Banaran. Selama ini, Kampoeng Kopi Banaran baru memasarkan produk-produk yang dimilikinya dengan menggunakan website, brosur, dan promosi mulut ke mulut. Berdasarkan hal tersebut, penelitian ini bertujuan untuk mengidentifikasi kriteria dan subkriteria yang tepat bagi penyusunan strategi pemasaran dari Kampoeng Kopi Banaran, menentukan bobot dari setiap kriteria dan subkriteria tersebut, serta mengusulkan strategi pemasaran tertentu berdasarkan kriteria dan subkriteria tersebut. Dalam penelitian ini, terdapat delapan buah kriteria yang digunakan sebagai dasar untuk menyusun strategi pemasaran bagi Kampoeng Kopi Banaran, yaitu Managerial Capabilities (MC), Market Innovation Capabilities (MIC), Customer Linking Capabilities (CLC), Human Resource Assetes (HRA), Reputational Asset (RA), Competition (C), Economy (E), dan Social and cultural (SC). Selanjutnya kedelapan kriteria tersebut akan dijabarkan lagi menjadi sejumlah subkriteria. Metoda yang digunakan untuk menghitung bobot dari kriteria dan subkriteria adalah Analitycal Network Process (ANP); sedangkan metoda yang digunakan untuk penyusunan strategi pemasaran adalah Technique for Others Reference by Similarity to Ideal Solution (TOPSIS ). Data untuk penelitian ini diperoleh dengan melakukan penyebaran kuesioner kepada manager dan bagian marketing Kampoeng Kopi Banaran. Hasil pengolahan data menunjukkan kriteria yang memiliki bobot tertinggi untuk penyusunan strategi pemasaran di Kampoeng Kopi Banaran adalah Managerial Capabilities (MC) $(0,1897)$ dan sub kriteria yagn memiliki bobot tertinggi adalah subkriteria brand atau reputasi $(0,1277)$. Selanjutnya, strategi yang terbaik untuk pemasaran Kampoeng Kopi Banaran adalah Strategi Segmentasi
\end{abstract}

Kata Kunci : strategi pemasaran; kampoeng kopi banaran; analytical network process (ANP); TOPSIS

\begin{abstract}
Kampoeng Kopi Banaran can't achieve a return in accordance with the targets set. Hypothesized, this is the case because of the increasing number of competitors with similar business, such as Cimory, Kampoeng Rawa, Tlogo Plantation, Salib Putih, and Umbul Sidomukti and have not had a proper marketing strategy by Kampoeng Kopi Banaran. During this time, Kampoeng Kopi Banaran has been promote its products by using the website, brochures, and word of mouth. According to this condition, this study aimed to identify the appropriate criteria and sub-criteria for the formulation of a marketing strategy for Kampoeng Kopi Banaran, determine the weight of each criteria and sub-criteria, as well as proposing specific marketing strategies based on the criteria and sub-criteria. In this study, there are eight criteria used as a basis to develop a marketing strategy for Kampoeng Kopi Banaran, namely Managerial Capabilities (MC), Market Innovation Capabilities (MIC), Customer Linking Capabilities
\end{abstract}

\footnotetext{
${ }^{*)}$ Penulis Korespondensi.

email: ariessusanty@gmail.com, woroputri@gmail.com
} 
(CLC), Human Resource Assetes (HRA), Reputational assets (RA), Competition (C), Economy (E), and Social and cultural (SC). Meanwhile, the eight criterias will be further elaborated into a number of subcriterias. The method is used to calculate weights of criteria and sub-criteria was Analytical Network Process (ANP) whereas the method is used for the preparation of a marketing strategy was Technique for Others Reference by Similarity to Ideal Solution (TOPSIS). Data for this study were obtain by distributing questionnaires for managers and marketing section at Kampoeng Kopi Banaran. The results of data was processing show that the criteria with the highest weight in the marketing strategy for the preparation at Kampoeng Kopi Banaran is Managerial Capabilities (MC) (0.1897) and sub-criteria with the highest weight is brand or reputation (0.1277). Meanwhile, the best strategy at Kampoeng Kopi Banaran is Segmentation Strategy

Keywords: selection of marketing strategy; kampoeng kopi banran; analytical network process (ANP); TOPSIS

\section{Pendahuluan}

Kebutuhan adalah segala sesuatu yang diperlukan manusia dalam hidupnya, yang bisa diperoleh dengan cara memiliki atau menikmati suatu barang atau jasa (Deliarnov, 2007). Kebutuhan dipengaruhi oleh tingkat pendapatan, semakin tinggi tingkat pendapatan maka semakin banyak kebutuhan yang harus dipenuhi (Keynes, 2009). Pada jaman sekarang wisata dan kuliner merupakan salah satu yang menjadi gaya hidup masyarakat terutama masyarakat di kota besar seperti Semarang. Salah satu yang menjadi kebutuhan masyarakat di kota besar seperti Semarang adalah wisata dan kuliner yang telah menjadi gaya hidup masyarakat (Suryani, 2013). Oleh sebab itu semakin banyak tempat wisata dan rekreasi yang dilengkapi dengan kuliner di kota semarang dengan berbagai jenis makanan serta fasilitas yang ditawarkan untuk semakin menarik minat konsumen. Semakin banyak munculnya usaha baru yang sejenis memberikan ancaman kepada pengusaha lama terhadap usahanya. Oleh sebab itu membutuhkan strategi pemasaran untuk tetap mempertahankan dan meningkatkan usaha (Kotler, 2000).

Kampoeng Kopi Banaran merupakan salah satu wisata agro yang dimiliki oleh PT. Perkebunan Nusantara IX (Persero), Terletak di Areal Perkebunan Kopi Kebun Getas Afdeling Assinan tepatnya Jl. Raya Semarang - Solo Km. 35. Fasilitas utama berupa bangunan untuk menikmati sedapnya kopi yaitu Banaran Caffee. Selain itu faisilitas juga dibangun arena bermain anak - anak, lapangan tenis, Mushola, Meeting Room, Griya Robusta, Family Gathering, Corporate Gathering, Coffee Walk, Out Bound Games, Kolam Renang, Gasebo, Taman Buah, Gedung Pertemuan, Flying Fox, Jelajah Kebun dengan ATV. Selama ini Kampoeng Kopi Banaran memasarkan menggunakan website, brosur, mulut kemulut dan belum ada strategi pemasaran yang pasti untuk meningkatkan dan tetap mempertahankan usahanya. Selama bulan Januari 2013 sampai Desember 2013 tingkat laba Kampoeng Kopi Banaran berfluktuasi ada beberapa bulan yang tidak mencapai target yang diharapkan.

J@TI Undip, Vol IX, No 3, September 2014
Berdasarkan data yang diperoleh dapat dilihat bahwa pada bulan Januari, Agustus, Oktober, November, Desember Laba Kampoeng Kopi Banaran sesuai target yang diharapkan tetapi pada bulan Februari, Maret, April, Mei, Juni, Juli, dan September Pencapaian Laba Kampeong Kopi Banaran tidak mencapai target sesuai yang ditargetkan. Bulan Januari, Agustus, Oktober, November laba mencapai target disebabkan pada bulan-bulan tersebut merupakan bulan libur sekolah, libur lebaran, libur natal dan libur tahun baru. Pada bulan-bulan biasa seperti bulan Februari, Maret, April, Mei, Juni, Juli, dan September laba tidak mencapai target yang diharapkan. Diduga dengan belum adanya strategi pemasaran yang optimal dan semakin banyaknya pesaing dengan usaha sejenis, seperti Cimory, Kampoeng Rawa, Tlogo Plantation, Salib Putih, Umbul Sidomukti semakin memberikan ancaman kepada Kampoeng Kopi Banaran yang dapat berakibat pada tidak tercapainya laba sesuai yang diharapkan. Kampoeng Kopi Banaran belum memilki strategi pemasaran yang optimal sehingga untuk tetap mempertahankan dan meningkatkan usahanya serta dapat mencapai target laba diharapkan, maka diperlukan strategi pemasaran.

Proses menentukan strategi pemasaran dapat dilakukan dengan Multiple criteria decision making (MCDM). Dalam penelitian ini digunakan metode Analitycal Network Process (ANP) dan Metode Technique for Others Reference by Similarity to Ideal Solution (TOPSIS). Langkah awal dalam peneltian ini adalah menentukan bobot kepentingan kriteria dan subkriteria dengan menggunakan metode ANP kemudian untuk menentukan strategi pemasaran yang sesuai dengan Kampoeng Kopi Banaran dengan menggunakan metode TOPSIS. Strategi Pemasaran yang digunakan dalam penelitian ini adalah strategi cost leadership, strategi differensiasi, strategi segmentasi (Porter, 1980). Tujuan dari penelitian ini adalah mengidentifikasi kriteria dan subkriteria yang mempengaruhi strategi pemasaran yang akan digunakan, menentukan bobot kepentingan subkriteria strategi pemasaran, mengusulkan strategi pemasaran berdasarkan hasil perhitungan TOPSIS. 


\section{Metodologi Penelitian}

Metodologi penelitian penelitian ini terdiri dari penentuan kriteria dan subkriteria, penentuan hubungan kriteria dan subkriteria, perancangan kuesioner, penyebaran kuesioner, penentuan bobot menggunakan metode ANP dan pemilihan strategi pemasaran menggunakan TOPSIS.

\section{Kriteria dan Subkriteria}

Kriteria yang digunakan berdasarkan penelitian Wu, dkk (2010) terdapat 5 kriteria pemilihan strategi pemasaran berdasarkan Hooley (2005) yaitu managerial capabilities, customer linking capabilities, market innovation capabilities, human resources assets dan reputational assets dan menurut Kotler (2008), terdapat beberapa kriteria eksternal yang mempengaruhi strategi pemasaran. Adapun kriteria yang sesuai dengan kondisi Kampoeng Kopi Banaran adalah Economy, Competition, Sosial and culture. Berikut adalah kriteria dan subkriteria yang digunakan dalam penelitian ini:

1. Managerial Capabilities, dengan sub kriteria yaitu Kondisi Finansial, Manajemen SDM yang efektif, Manajemen operasi yang baik, Manajemen Pelayanan

2. Customer Linking Capabilitie, dengan sub kriteria yaitu Tingkat Layanan konsumen, Hubungan dengan target utama konsumen, Memahami Kebutuhan Konsumen, Membangun hubungan dengan konsumen, Mempertahankan dan Meningkatkan hubungan dengan konsumen

3. Market Innovation Capabilities, dengan sub kriteria yaitu Kemampuan meluncurkan produk dan layanan baru, Proses pengembangan produk dan layanan baru yang efektif

4. Human Resource Assets, dengan sub kriteria yaitu Tingkat kepuasan kinerja karyawan, Retensi karyawan

5. Reputational Assets, dengan sub kriteria yaitu Brand atau Reputasi, Kredibilitas

6. Ekonomi, dengan sub kriteria yaitu Peningkatan Pendapatan, Inflasi, Resesi

7. Sosial and Culture, dengan sub kriteria yaitu Group reference, Peran dan status di masyarakat

8. Competition, dengan sub kriteria yaitu Keberadaan Persaingan segmen yang ketat, Keberadaan Pendatang Baru, Keberadaan Produk Substitusi

\section{Penentuan Hubungan Kriteria dan subkriteria}

Penentuan hubungan saling ketergantungan dilakukan berdasarkan metode voting hasil penelitian oleh Kasirian dan Yusuff (2009). Hasil dari hubungan ketergantungan subkriteria. Jumlah responden (N) adalah lima orang. Jika dalah suatu blok (baris i kolom j), jumlah responden yang memilih (Vij) lebih dari atau sama dengan $(\mathrm{N} / 2 \geq 2,5)$, maka terdapat hubungan keterkaitan antar kriteria tersebut. Dari hubungan ini, nantinya akan menjadi dasar dalam pembuata model ANP dengan menggunakan software super decision.

\section{Perancangan Kuesioner}

Pada penelitian ini terdapat 3 kuesioner yang digunakan, dimana ketiga kuesioner ini harus dilakukan secara berurutan. Kuesioner yang pertama disebarkan adalah kuesioner hubungan antar kriteria. Kuesioner ini bertujuan untuk mengetahui hubungan ketergantungan antar subkriteria sebagai acuan dasar untuk membuat model ANP. Kuesioner yang kedua adalah kuesioner perbandingan berpasangan. Kuesioner ini dibuat berdasarkan hubungan ketergantungan yang didapatkan dari kuesioner pertama. Kuesioner yang ketiga adalah kuesioner judgment metode TOPSIS. Kuesioner ini berfungsi untuk mengetahui kesesuaian alternatif strategi yang ada terhadap sumber daya pemasaran yang dimiliki oleh perusahaan saat ini.

\section{Penyebaran Kuesioner}

Penyebaran kuesioner pada peneltian ini dibagi 2 untuk penentuan hubungan ketergantungan antar subkriteria kepada kepada staff ahli marketing Kampoeng Kopi Banaran, manajer Kampoeng Kopi Banaran dan Dosen Manajamen Pemasaran Fakultas Ekonomika dan Bisnis Universitas Diponegoro. Penyebaran kuesioner untuk metode ANP dan TOPSIS kepada kepada staff ahli marketing Kampoeng Kopi Banaran, manajer Kampoeng Kopi Banaran.

\section{Penentuan Bobot Menggunakan Metode ANP}

Dalam melakukan pengolahan data berdasarkan hasil penilaian dari kuisioner yang disebarkan ke beberapa responden, berikut langkah-langkah perhitungannya dengan menggunakan Software Super Decision (Saaty, 1998):

1. Menghitung nilai geometric mean, tujuan dari perhitungan geometric mean ialah mengkumulatifkan jawaban responden dalam sebuah formula untuk mendapatkan sebuah keputusan, dengan kata lain nilai geometric mean merupakan jawaban bersama, dari beberapa responden dalam mendapatkan satu jawaban

2. Memasukkan hasil perhitungan mean geometris kedalam software super decision

3. Melakukan uji konsistensi, hasil kuesioner berpasangan akan diuji kekonsistenannya melihat nilai $C R$ harus lebih kecil dari 0,1 . Suatu matriks perbandingan berpasangan akan konsisten bila indeks inkonsistensinya berada dibawah nilai 0,1 . Hal tersebut penting karena tanpa adanya ketidak konsistensian maka perubahan yang mempengaruhi tingkat preferensi tidak berlaku 
4. Menentukan bobot kepentingan subkriteria. Bobot kepentingan subkriteria didapat dari menormalisasikan nilai limiting pada setiap elemen

\section{Pemilihan Strategi Pemasaran Menggunakan Metode TOPSIS}

Setelah didapatkan bobot kepentingan untuk masing-masing subkriteria maka tahapan selanjutnya adalah meranking prioritas untuk alternatif strategi pemasaran terpilih yang dianggap paling sesuai untuk Kampoeng Kopi Banaran. Pada penelitian ini, metode yang digunakan untuk merangking prioritas adalah dengan menggunakan metode TOPSIS. Metode ini dipilih karena dengan menggunakan TOPSIS, alternatif yang nantinya terpilih memiliki jarak terdekat dengan solusi ideal, dan jarak terjauh dengan solusi ideal negatif.

Metode ini memiliki prinsip dasar yaitu bahwa alternatif yang terpilih haruslah memiliki jarak terdekat dari solusi ideal dan jarak terjauh dari solusi negatif-ideal Solusi ideal positif didefiniskan sebagai jumlah dari seluruh nilai terbaik yang dapat dicapai untuk setiap atribut, sedangkan solusi negatif-ideal terdiri dari seluruh nilai terburuk yang dapat dicapai untuk setiap atribut. TOPSIS mempertimbangkan keduanya, jarak terhadap solusi ideal positif dan terhadap solusi ideal negatif dengan mengambil kedekatan relatif terhadap solusi ideal positif. Adapun tahapan metode TOPSIS sebagai berikut:

1. Menghitung matriks keputusan ternormalisasi.

Persamaan digunakan untuk mentransformasikan setiap elemen $x_{i j}$ adalah

$$
r_{b j}=\frac{r_{i j}}{\sqrt{\sum_{i=1}^{m} X_{\eta j}^{2}}}
$$

2. Membuat matriks keputusan yang ternormalisasi terbobot.

Dengan bobot $w_{l}=\left(w_{1}, w_{2}, w_{3}, \ldots, w_{m}\right)$, dimana

$w_{j}$ adalah bobot dari kriteria ke-j dan $\sum_{j-1}^{n} w_{j}=1$ maka normalisasi bobot matriks $\mathrm{V}$ adalah $v_{i j}=w_{j} r_{t j}$

3. Menentukan matriks solusi ideal positif dan solusi ideal negatif.

Solusi ideal positif dinotasikan $\mathrm{A}^{+}$, sedangkan solusi ideal negatif dinotasikan $A^{-}$, Berikut ini adalah persamaan dari $A^{+}$dan $A^{-}$:

a. $A^{+}\left\{\left(\max v_{i j} \mid \mathrm{j} € \mathrm{~J}\right),\left(\min v_{i j} \mid \mathrm{j} € \mathrm{~J}^{\prime}\right), \mathrm{i}=1,2\right.$, $3, \ldots, \mathrm{m}\} \ldots . .(3)$

$=\left\{v_{1}^{+}, v_{2}^{+}, v_{3}^{+}, \ldots, v_{n}^{+}\right\}$

b. $A \quad\left\{\left(\min v_{i j} \mid \mathrm{j} € \mathrm{~J}\right),\left(\max v_{i j} \mid \mathrm{j} € \mathrm{~J} '\right), \mathrm{i}=1\right.$, $2,3, \ldots, \mathrm{m}\} \ldots(4)$

$$
=\left\{v_{1}^{-}, v_{2}^{-}, v_{3}^{-}, \ldots, v_{n}^{-}\right\}
$$

$\mathbf{J}=\{\mathrm{j}=1,2,3, \ldots, \mathrm{n}$ dan $\mathbf{J}$ merupakan himpunan kriteria keuntungan (benefit criteria)\}.

$\mathrm{J}^{\prime}=\left\{\mathrm{j}=1,2,3, \ldots, \mathrm{n}\right.$ dan $\mathrm{J}^{\prime}$ merupakan himpunan kriteria biaya (cost criteria) \}.

4. Menghitung separasi.

a. 5 radalah jarak alternatif dari solusi ideal positif didefinisikan sebagai:

$S_{i}^{+}=\sqrt{\sum_{j=1}^{n}\left(V_{i j}-V_{I}^{+}\right)^{2}}, \ldots(5)$

b. $s^{-}$adalah jarak alternatif dari solusi ideal negatif didefinisikan sebagai:

$$
S_{i}^{-}=\sqrt{\sum_{j=1}^{n}\left(V_{i j}-V_{I}^{-}\right)^{2}}, \ldots(6)
$$

5. Menghitung kedekatan relatif terhadap solusi ideal positif.

Kedekatan relatif dari setiap alternatif terhadap solusi ideal positif dapat dihitung dengan menggunakan persamaan berikut:

$$
c_{i}^{+}=\frac{s_{i}^{-}}{\left(s_{i}^{-}+s_{i}^{+}\right)}, 0 \leq c_{i}^{+} \leq \ldots \ldots . .(7)
$$

6. Merangking Alternatif.

Alternatif diurutkan dari nilai $C^{+}$terbesar ke nilai terkecil. Alternatif dengan nilai $C^{+}$terbesar merupakan solusi yang terbaik.

Keterangan:

i : $1,2,3, \ldots, \mathrm{m}$

$\mathrm{j}: 1,2,3, \ldots, \mathrm{n}$

$r_{t j}$ :elemen dari matriks keputusan yang

ternormalisai $\mathrm{R}$

$x_{i j}$ :elemen dari matriks keputusan $\mathrm{X}$

$v_{i j}$ : elemen dari matriks keputusan yang

ternormalisai terbobot $\mathrm{V}$

$w_{1}:$ bobot dari kriteria ke-j

$s_{i}^{+}$: jarak alternatif ke-i dari solusi ideal positif

$s_{i}^{-}$: jarak alternatif ke-i dari solusi ideal negatif

$v_{i j}$ : elemen dari matriks keputusan yang ternormalisai terbobot $\mathrm{V}$

$v_{j}^{+}$: elemen matriks solusi ideal positif

$v_{j}^{-}$: adalah elemen matriks solusi ideal negatif

$c_{t}^{+}$: kedekatan relatif dari alternatif ke-i terhadap solusi ideal positif,

$s_{l}^{+}$: jarak alternatif ke-i dari solusi ideal positif

$s_{i}^{-}$: jarak alternatif ke-i dari solusi ideal negatif

\section{Hasil Dan Pembahasan}

Hasil dari penelitian adalah hubungan antar subkriteria strategi pemasaran, bobot kepentingan tiap subkriteria dan pemilihan strategi pemasaran 


\section{Hubungan Keterkaitan Antar Sub Kriteria}

Berdasarkan dari hasil kuesioner, dapat diidentifikasi ada atau tidaknya hubungan antar kriteria dan subkriteriadan dapat diidentifikasi hubungan inner dependence dan outer dependence dari masing-masing subkriteria. Dari hubungan antar subkriteria dan kriteria ini, dapat dibuat suatu model pemilihan strategi pemasaran di Kampoeng Kopi Banaran yang mengacu pada metode ANP. Hasil kuesioner hubungan keterkaitan antar subkriteria dan kerangka ANP dapat dilihat pada Appendix.

\section{Bobot Kepentingan Subkriteria}

Penentuan bobot kepentingan tiap subkriteria menggunakan metode ANP. Dalam menggunakan metode ANP dibutuhkan kerangka ANP. Kerangka ANP yang digunakan dalam penelitian ini sesuai dengan output hubungan subkriteria pada tahapan sebelumnya. Kerangka ANP pada penelitian di Kampoeng Kopi Banaran dapat dilihat pada Gambar 1. Tahapan selanjutnya setelah membuat kerangka ANP adalah menginput hasil kuesioner perbandingan berpasangan yang telah diisi oleh responden. Hal yang perlu diperhatikan dalam mengolah data menggunakan ANP adalah nilai inconsistency harus kurang dari 0,1 .

Dalam penentuan bobot kepentingan subkriteria hal pertama yang dilakukan adalah menghitung mean geometris. Tujuan dari perhitungan geometric mean ialah mengkumulatifkan jawaban responden dalam sebuah formula untuk mendapatkan sebuah keputusan, dengan kata lain nilai geometric mean merupakan jawaban bersama, dari beberapa responden dalam mendapatkan satu jawaban. Setelah mendpatkan hasil mean geometris maka memasukkan hasil perbandingan kedalam software Super Decision, dan melihat nilai inconsistency. Dari perhitungan dilihat output rasio konsistensi gabungan memilki nilai 0,1 sehingga matriks perbandingan berpasangan konsisten sehingga tidak diperlukan perbaikan dalam pengambilan keputusan perbandingan berpasangan. Langkah selanjutnya adalah menghitung bobot kepentingan subkriteria yang didapatan dari output software super decision. Hasil rekapitulasi output bobot kepentingan untuk subkriteria dalam kriteria masing-masing dapat dilihat pada Tabel 1 .

Tabel 1 menunjukkan nilai bobot kepentingan setiap subkriteria yang dapat dilihat pada kolom bobot yang akan digunakan dalam perhitungan TOPSIS untuk menentukan strategi pemasaran yang tepat dengan Kampoeng Kopi Banaran. Nilai bobot kepentingan subkriteria dapat dilihat pada limiting. Subkriteria yang memilki bobot kepentingan paling tinggi adalah Brand atau reputasi yaitu sebesar 0.1277 .
Tabel 1. Bobot kepentingan subkriteria dan nilai inconsistency

\begin{tabular}{|c|c|c|}
\hline Subkriteria & Bobot & Inconsistensy \\
\hline Kondisi Finansial & 0,0452 & 0,0000 \\
\hline $\begin{array}{l}\text { Manajemen SDM yang } \\
\text { efektif }\end{array}$ & 0,0222 & 0,0320 \\
\hline $\begin{array}{l}\text { Manajemen operasi yang } \\
\text { baik }\end{array}$ & 0,0637 & 0,0117 \\
\hline $\begin{array}{l}\text { Manajemen Pelayanan } \\
\text { Tingkat layanan }\end{array}$ & 0,0189 & 0,0704 \\
\hline konsumen & 0,0744 & 0,0806 \\
\hline $\begin{array}{l}\text { Hubungan dengan target } \\
\text { utama konsumen }\end{array}$ & 0,0412 & 0,0000 \\
\hline $\begin{array}{l}\text { Memahami kebutuhan } \\
\text { konsumen }\end{array}$ & 0,1133 & 0,0172 \\
\hline $\begin{array}{l}\text { Membangun hubungan } \\
\text { dengan konsumen }\end{array}$ & 0,0974 & 0,0454 \\
\hline $\begin{array}{l}\text { Mempertahan } \\
\text { meningkatkan hubungan } \\
\text { konsumen }\end{array}$ & 0,0740 & 0,0000 \\
\hline $\begin{array}{l}\text { Kemampuan } \\
\text { meluncurkan produk } \\
\text { layanan baru }\end{array}$ & 0,0756 & 0,0579 \\
\hline $\begin{array}{l}\text { Proses pengembangan } \\
\text { produk layanan baru } \\
\text { efektif }\end{array}$ & 0,0761 & 0,0427 \\
\hline $\begin{array}{l}\text { Tingkat kepuasan kinerja } \\
\text { karyawan }\end{array}$ & 0,0070 & 0,0442 \\
\hline Retensi karyawan & 0,0112 & 0,0000 \\
\hline Brand atau Reputasi & 0,1277 & 0,0707 \\
\hline Kredibilitas & 0,0595 & 0,0065 \\
\hline Peningkatan Pendapatan & 0,0000 & 0,0176 \\
\hline Inflasi & 0,0000 & 0,0000 \\
\hline Resesi & 0,0000 & 0,0176 \\
\hline Group Reference & 0,0000 & 0,0000 \\
\hline $\begin{array}{l}\text { Peran dan status di } \\
\text { masyarakat }\end{array}$ & 0,0000 & 0,0516 \\
\hline $\begin{array}{l}\text { Keberadaan Persaingan } \\
\text { segmen yang ketat }\end{array}$ & 0,0405 & 0,0323 \\
\hline $\begin{array}{l}\text { Keberadaan pendatang } \\
\text { baru }\end{array}$ & 0,0351 & 0,0311 \\
\hline $\begin{array}{l}\text { Keberadaan produk } \\
\text { substitusi }\end{array}$ & 0,0167 & 0,0516 \\
\hline
\end{tabular}

Analisis dan Penentuan Prioritas Alternatif Terpilih dengan Metode Technique for order preference by similarity to an ideal solution (TOPSIS)

1. Membuat Matriks Keputusan

Matriks Keputusan didapat dari perhitungan hasil kuesioner yaitu dengan cara merata-rata hasil kuesioner yang dibagikan kepada responden. Berikut adalah Hasil mariks Keputusan : 
Tabel 2. Matriks Keputusan

\begin{tabular}{cccc}
\hline & CS & DS & SS \\
\hline KF & 3,33 & 3,00 & 3,00 \\
MS & 3,00 & 3,00 & 3,67 \\
MO & 2,67 & 3,33 & 3,00 \\
MP & 2,33 & 3,33 & 4,33 \\
TL & 2,33 & 3,67 & 4,33 \\
HT & 3,00 & 3,00 & 4,67 \\
MK & 3,00 & 3,33 & 4,00 \\
MH & 3,00 & 3,00 & 4,33 \\
MM & 2,67 & 3,00 & 3,00 \\
KM & 2,67 & 3,33 & 3,67 \\
PPP & 3,00 & 3,33 & 4,00 \\
TK & 2,33 & 2,33 & 3,67 \\
RK & 3,00 & 2,67 & 3,67 \\
BR & 2,67 & 3,00 & 4,00 \\
KD & 2,67 & 3,00 & 3,33 \\
PP & 3,33 & 3,00 & 3,33 \\
IF & 2,33 & 2,67 & 2,33 \\
RS & 3,00 & 2,33 & 2,67 \\
GR & 2,00 & 3,00 & 4,00 \\
PS & 2,00 & 2,33 & 3,67 \\
KP & 2,67 & 3,67 & 3,33 \\
KPB & 3,00 & 3,33 & 3,33 \\
KPS & 2,00 & 2,67 & 2,33 \\
\hline
\end{tabular}

2. Normalisasi Matriks Keputusan

Tahap selanjutnya adalah menghitung matriks keputusan normal. Matriks keputusan dapat dilihat pada Tabel 2. Nilai normalisasi dihitung dengan menggunakan rumus 1 .

3. Matriks keputusan normalisasi terbobot

Tahap selanjutnya, setelah melakukan perhitungan normalisasi matriks keputusan langkah selanjutnya adalah membuat matriks keputusan normalisasi terbobot dengan menggunakan bobot kepentingan setiap subkriteria pada Tabel 1. Nilai normalisasi dihitung dengan menggunakan rumus 2 .

4. Menghitung Solusi ideal

Tahap selanjutnya adalah menghtiung solusi ideal positif daan solusi ideal negatif. Perhitungan solusi ideal dengan menggunakan rumus 3 dan 4 dengan berdasarkan matriks keputusan ternormalisasi terboobot pada Tabel 4.

Keterangan :

CS : Cost Leadership Strategy

DS : Differentiation Strategy

SS : Segmentation Strategy

KF : Kondisi Finansial
MS : Manajemen SDM yang efektif

MO : Manajemen operasi yang baik

MP : Manajemen Pelayanan

TL : Tingkat layanan konsumen

HT : Hubungan dengan target utama konsumen

MK : Memahami kebutuhan konsumen

MH : Membangun hubungan dengan konsumen

: Mempertahan meningkat hubungan

MM konsumen

: Kemampuan meluncurkan produk layanan

KM baru

PPP : Proses pengembangan produk layanan

efektif

TK : Tingkat kepuasan kinerja karyawan

RK : Retensi karyawan

BR : Brand atau Reputasi

KD : Kredibilitas

PP : Peningkatan Pendapatan

IF : Inflasi

RS : Resesi

GR : Group Reference

PS : Peran dan status di masyarakat

KP : Keberadaan Persaingan segmen yang ketat

KPB : Keberadaan pendatang baru

KPS : Keberadaan produk substitusi

Tabel 3. Normalisasi Matriks Keputusan

\begin{tabular}{cccc}
\hline & CS & DS & SS \\
\hline KF & 0,6178 & 0,5560 & 0,5560 \\
MS & 0,5350 & 0,5350 & 0,6539 \\
MO & 0,5111 & 0,6389 & 0,5750 \\
MP & 0,3925 & 0,5608 & 0,7290 \\
TL & 0,3802 & 0,5974 & 0,7061 \\
HT & 0,4757 & 0,4757 & 0,7399 \\
MK & 0,4992 & 0,5547 & 0,6656 \\
MH & 0,4947 & 0,4947 & 0,7145 \\
MM & 0,5322 & 0,5987 & 0,5987 \\
KM & 0,4739 & 0,5923 & 0,6516 \\
PPP & 0,4992 & 0,5547 & 0,6656 \\
TK & 0,4730 & 0,4730 & 0,7433 \\
RK & 0,5518 & 0,4905 & 0,6745 \\
BR & 0,4706 & 0,5294 & 0,7059 \\
KD & 0,5111 & 0,5750 & 0,6389 \\
PP & 0,5965 & 0,5369 & 0,5965 \\
IF & 0,5500 & 0,6285 & 0,5500 \\
RS & 0,6462 & 0,5026 & 0,5744 \\
GR & 0,3714 & 0,5571 & 0,7428 \\
PS & 0,4180 & 0,4877 & 0,7664 \\
KP & 0,4739 & 0,6516 & 0,5923 \\
KPB & 0,5369 & 0,5965 & 0,5965 \\
KPS & 0,4915 & 0,6554 & 0,5735 \\
\hline & & & \\
\hline
\end{tabular}


Tabel 4. Matriks Keputusan Ternormalisasi Terbobot

\begin{tabular}{cccc}
\hline & CS & DS & SS \\
\hline KF & 0,0279 & 0,0251 & 0,0251 \\
MS & 0,0119 & 0,0119 & 0,0145 \\
MO & 0,0326 & 0,0407 & 0,0366 \\
MP & 0,0074 & 0,0106 & 0,0138 \\
TL & 0,0283 & 0,0445 & 0,0526 \\
HT & 0,0196 & 0,0196 & 0,0305 \\
MK & 0,0566 & 0,0628 & 0,0754 \\
MH & 0,0482 & 0,0482 & 0,0696 \\
MM & 0,0394 & 0,0443 & 0,0443 \\
KM & 0,0358 & 0,0448 & 0,0493 \\
PPP & 0,0380 & 0,0422 & 0,0506 \\
TK & 0,0033 & 0,0033 & 0,0052 \\
RK & 0,0062 & 0,0055 & 0,0076 \\
BR & 0,0601 & 0,0676 & 0,0901 \\
KD & 0,0304 & 0,0342 & 0,0380 \\
PP & 0,0000 & 0,0000 & 0,0000 \\
IF & 0,0000 & 0,0000 & 0,0000 \\
RS & 0,0000 & 0,0000 & 0,0000 \\
GR & 0,0000 & 0,0000 & 0,0000 \\
PS & 0,0000 & 0,0000 & 0,0000 \\
KP & 0,0192 & 0,0264 & 0,0240 \\
KPB & 0,0189 & 0,0210 & 0,0210 \\
KPS & 0,0082 & 0,0109 & 0,0096 \\
\hline & & &
\end{tabular}

5. Menetukan Separasi

Tahap selanjutnya setelah diperoleh solusi ideal positif dan solusi ideal negatif adalah menghitung separasi/jarak antara nilai terbobot setiap alternatif. Perhitungan jarak antara nilai terbobot setiap alternatif digunakan rumus 5 dan6 Berikut adalah hasil nya :

Jarak antara nilai terbobot setiap alternatif terhadap solusi ideal positif

$s 1^{\prime}=0.0550$

$S 2^{+}=0.0380$

$s 3^{+}=0.0057$

Jarak antara nilai terbobot setiap alternatif terhadap solusi ideal negatif

$S 1^{-}=0.0028$

$s 2^{-}=0.0251$

$s 3^{-}=0.0542$

6. Alternatif Strategi

Langkah selanjutnya adalah menghitung setiap alternatif terhadap solusi ideal. Nilai kedekatan dihitung dengan menggunakan rumus 7 .

Perhitungan dapat dilihat sebagai berikut :

$$
\mathrm{C} 1=0.0028 /(0.0028+0.0550)
$$

J@TI Undip, Vol IX, No 3, September 2014

$$
\begin{aligned}
& =0.0496 \\
\mathrm{C} 2 & =0.0251 /(0.0251+0.0380) \\
& =0.3983 \\
\mathrm{C} 3 & =0.0542 /(0.0542+0.0057) \\
& =0.9056
\end{aligned}
$$

Dari perhitungan, dapat dilihat bahwa nilai kedekatan untuk masing-masing alternatif cost leadership strategy 0.0496, untuk alternatif differentiation 0.3983 dan untuk segmentation strategy 0.9056. Dengan demikian dapat disimpulkan bahwa dipeorleh ranking yang memilki nilai paling besar dari ketiga alternatif adalah segmentation strategy.

Tabel 4. Rekap Solusi ideal positif dan Solusi ideal negative

\begin{tabular}{crr}
\hline & Solusi Positif & Solusi Negatif \\
\hline KF & 0.0279 & 0.0251 \\
MS & 0.0145 & 0.0119 \\
MO & 0.0407 & 0.0326 \\
MP & 0.0138 & 0.0074 \\
TL & 0.0526 & 0.0283 \\
HT & 0.0305 & 0.0196 \\
MK & 0.0754 & 0.0566 \\
MH & 0.0696 & 0.0482 \\
MM & 0.0443 & 0.0394 \\
KM & 0.0493 & 0.0358 \\
PPP & 0.0506 & 0.0380 \\
TK & 0.0052 & 0.0033 \\
RK & 0.0076 & 0.0055 \\
BR & 0.0901 & 0.0601 \\
KD & 0.0380 & 0.0304 \\
PP & 0.0000 & 0.0000 \\
IF & 0.0000 & 0.0000 \\
RS & 0.0000 & 0.0000 \\
GR & 0.0000 & 0.0000 \\
PS & 0.0000 & 0.0000 \\
KP & 0.0264 & 0.0192 \\
KPB & 0.0210 & 0.0189 \\
KPS & 0.0109 & 0.0082 \\
\hline
\end{tabular}

\section{Kesimpulan}

Kriteria yang digunakan pada penelitian ini adalah Managerial capabilities subkriterianya adalah kondisi finansial, manajemen SDM yang efektif, manajemen operasi yang baik, manajemen pelayanan. Kriteria kedua adalah Customer Linking capabilities, subkriterianya adalah tingkat layanan konsumen, hubungan dengan target utama konsumen, memahami kebutuhan konsumen, membangun hubungan dengan konsumen, mempertahankan dan meningkatkan hubungan hubungan dengan konsumen. Kriteria ketiga adalah Market innovation dengan subkriteria kemampuan meluncurkan produk baru, proses pengembangan roduk dan layanan baru yang efektif. Kriteria keempat adalah Human resource assets, subkriterianya adalah tingkat kepuasan kinerja 
karyawan, retensi karyawan. Kriteria kelima adalah Reputational assets dengan subkriterianya adalah brand atau reputasi dan kredibilitas. Kriteria keenam adalah economy, subkriterianya adalah peningkatan pendapatan, inflasi, resesi. Kriteria ketujuh adalah social and cultural dengan subkriterianya adalah group reference, peran dan status dimasyarakat. Kriteria kedelapan adalah competition dengan subkriterianya adalah keberadaan persaingan segmen yang ketat, keberadaan pendatang baru dan keberadaan produk substitusi.

Nilai bobot kepentingan paling tinggi pada subkriteria strategi pemasaran di Kampoeng Kopi Banaran adalah subkriteria brand atau reputasi $(0,1277)$, selanjutnya adalah adalah subkriteria memahami kebutuhan konsumen $(0,1133)$, subkriteria membangun hubungan dengan konsumen $(0,0974)$, subkriteria proses pengembangan produk layanan baru efektif $(0,0761)$, subkriteria kemampuan meluncurkan produk baru $(0,0756)$, subkriteria tingkat layanan konsumen $(0,0744)$, subkriteria mempertahankan meningkatkan hubungan konsumen $(0,0740)$, subkriteria manajemen operasi yang baik $(0,0637)$, subkriteria kredibilitas $(0,0595)$, subkriteria kondisi finansial $(0,0452)$, subkriteria hubungan dengan target utama konsumen $(0,0412)$ subkriteria keberadaan persaingan segmen yang ketat $(0,0405)$, subkriteria keberadaan pendatang baru $(0,0351)$, subkriteria manajemen SDM yang efektif $(0,0222)$, subkriteria manajemen pelayanan $(0,0189)$, subkriteria keberadaan produk substitusi $(0,0167)$, subkriteria retensi karyawan $(0,0112)$, subkriteria tingkat kepuasan kinerja karyawan $(0,0070)$ kemudian subkriteria peningkatan pendapatan, inflasi, resesi, group reference dan peran dan status dimasyarakat.

Strategi pemasaran yang terpilih untuk Kampoeng Kopi Banaran adalah strategi segmentasi, dikarenakan sesuai dengan subkriteria yang berpengaruh terhadap penerapan strategi pemasaran segmentasi di Kampoeng Kopi Banaran yaitu subkriteria brand atau reputasi, subkriteria memahami kebutuhan konsumen, subkriteria membangun hubungan dengan konsumen, subkriteria proses pengembangan produk layanan baru efektif, subkriteria kemampuan meluncurkan produk baru, subkriteria tingkat layanan konsumen, subkriteria mempertahankan meningkatkan hubungan konsumen, subkriteria manajemen operasi yang baik, subkriteria kredibilitas, subkriteria kondisi finansial, subkriteria hubungan dengan target utama konsumen, subkriteria keberadaan persaingan segmen yang ketat , subkriteria keberadaan pendatang baru, subkriteria manajemen SDM yang efektif, subkriteria manajemen pelayanan, subkriteria retensi karyawan, subkriteria tingkat kepuasan kinerja karyawan, kemudian subkriteria peningkatan pendapatan, resesi, group reference dan peran dan status dimasyarakat.

\section{Daftar Pustaka}

Deliarnov. 2007. Ekonomi. Erlangga: Jakarta

Deliarnov. 2007. Perkembangan Pemikiran Ekonomi. Raja Grafindo Persada: Jakarta

Kotler, P. 2000. Manajemen Pemasaran: Analisis, Perencanaan, Implementasi dan Kontrol. Prenhallindo: Jakarta

Porter, M.E., 1980. Competitive Strategy: Techniques for Analyzing Industries and Competitors, The Free Press: New York

Saaty, T., L., 1998. Decision Making with Dependence and Feedback: The Analytic Network Process. RWS Publication: Pittsburgh USA.

Saaty, T., L., dan Vargas, G 2006, Decision Making in Economic, Political, Social and Technological Enviroments with The Analytical Hierarchy Process, The Analytical Hierarchy Process. RWS Publication, Pittsburgh USA.

Suryani, T., 2013. Perilaku Konsumen di Era Globalisasi. Graha Ilmu: Yogyakarta

Tjiptono, F., Chandra, G, dan Andriana. 2007. Pemasaran Strategik. ANDI: Yogyakarta

Wu, C.S., Lin. C.T., Lee, C., 2010. Optimal marketing Strategy: A decision-making with ANP and TOPSIS. Int.J. Production Economics 127, 190-196 


\section{APPENDIX}

Tabel 5. Rekapitulasi kuesioner hubungan antar subkriteria

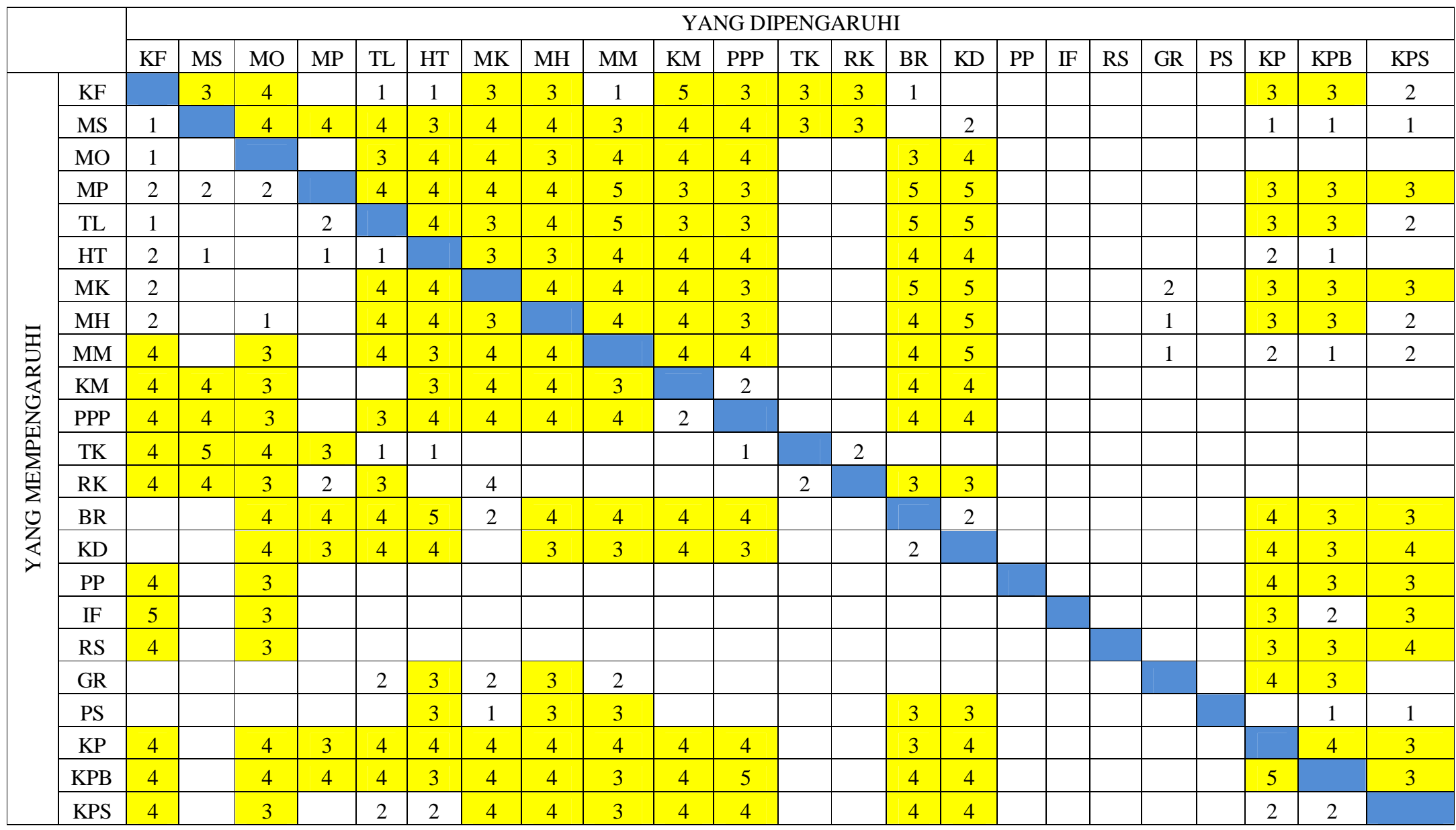




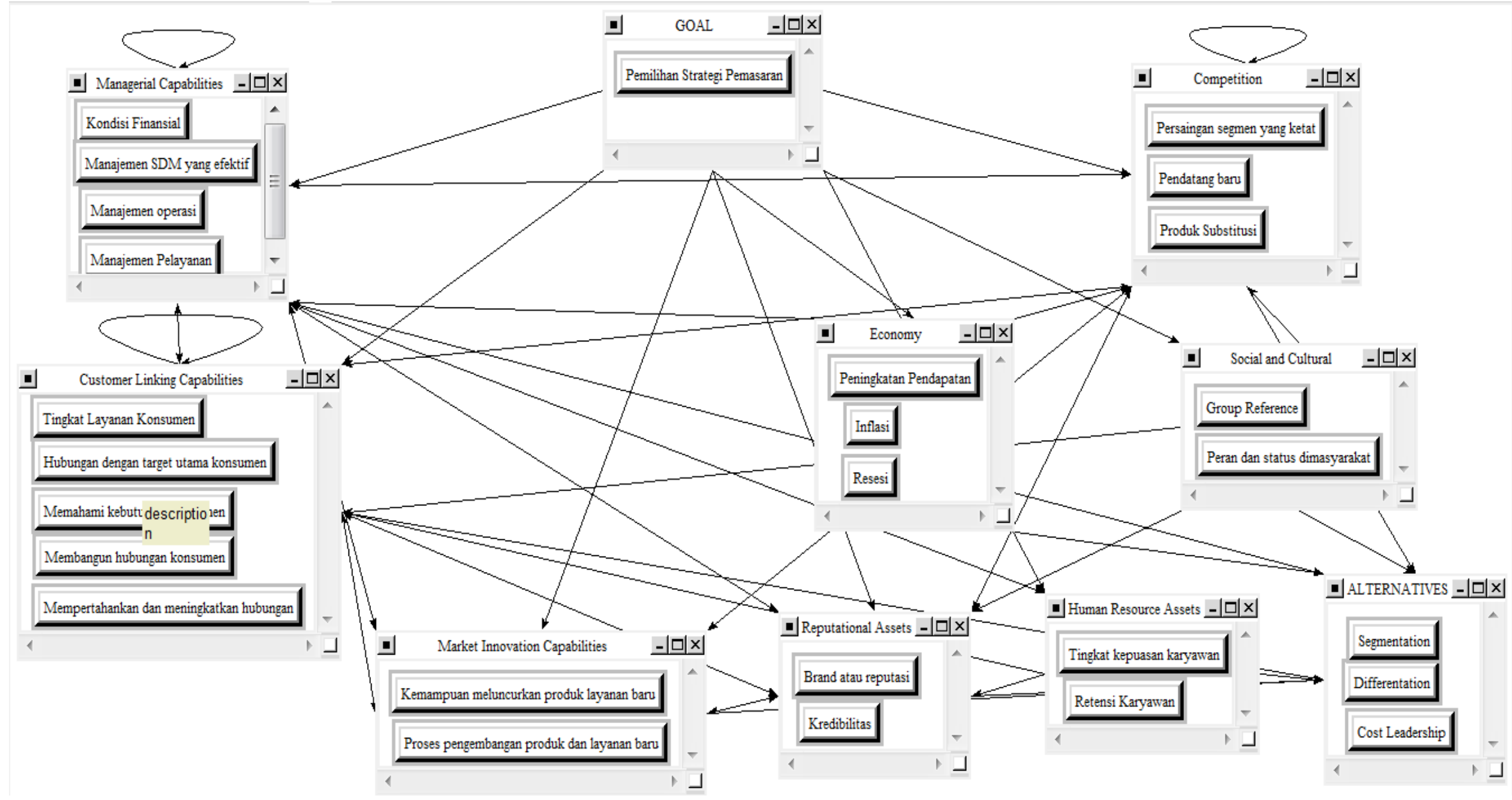

Gambar 1. Kerangka ANP 